\title{
Dumbing Down is Good for You
}

\author{
Mick Temple \\ Journalism and Politics, Staffordshire University. \\ E-mail: m.temple@staffs.ac.uk
}

There has been considerable academic debate about the 'dumbing down' of the media, most of it characterizing the process as having a negative impact upon democratic political discourse. This paper argues that the so-called dumbing down of political coverage is an essential part of engaging people on political issues and that popular television such as chat and reality shows capture and engage audiences unresponsive to more conventional coverage of social issues. A public sphere focussed on the rational and 'high-minded' coverage of politics is an inadequate representation of how most people receive political knowledge and make judgements about important issues. In addition, therefore, concerns about the dumbing down of 'serious' political outputs are misplaced. A less elite-driven news agenda - one that recognizes the importance of the emotional and the apparently trivial - offers wider opportunities for political engagement to all sections of society. Finally, the paper calls for more academic involvement in the task of providing entertaining yet authoritative introductions to political issues.

British Politics (2006) 1, 257-273. doi:10.1057/palgrave.bp.4200018

Keywords: dumbing down; public sphere; democracy

\section{Introduction}

This paper argues that the so called 'dumbing down' of political coverage, referring largely to the simplification and sensationalism of 'serious' news by journalists, is an essential part of the process of engaging people in debates about the distribution of resources in modern democratic societies. Not only that, but Trisha, Richard \& Judy and the Jerry Springer Show can (and do) capture and engage an audience who will fail to respond to more conventional coverage of social and 'political' issues. Equally importantly, coverage of popular culture by 'quality' titles and programmes, again cited as evidence of dumbing down, is essential in informing a more politically aware audience of trends in popular entertainment and culture which often impact on political behaviour. The argument is informed by reference to debates on the nature of the 'public sphere' (Habermas, 1989; Dahlgren, 1995). As Yeatman points out 'democratic discourse that is oriented in terms of a centric public sphere is truly anachronistic' (1994, 113). The public sphere needs to be reconceptualized in order to more accurately reflect that what Dahlgren (1995) has called the 
'mediated public sphere' comprises many (and multi-dimensional) public spheres. All forms of popular entertainment are constituents of the mediated public sphere.

The commercialization of the media is seen as responsible for both the 'effective elimination' (Street, 2001, 42) of Habermas's original notion of a 'rational critical public sphere' and to a dumbing down of political coverage. Concerns that dumbing down is responsible for the rise in public apathy about politics ignore the need for public spheres that will engage the politically illiterate or disenchanted in a way that will encourage them to participate in public debate. For example, there is little doubt that tabloid journalism, by ignoring 'serious politics' in favour of scandal and superficiality, is perceived by critics as constituting a threat to democracy. An alternative perspective is that a less elite-driven news agenda - one driven by the interests of the audience rather than by a small core of political journalists - offers the opportunity for engagement with political issues by those (the vast majority) uninterested in the minutiae of policy or the internal differences of the Conservative party. Those of us who are interested in deep debate about political issues will always find a forum, but in the age of television politics, insisting that our perceptions of politics should largely constitute the mainstream public sphere is an elitist and essentially futile exercise.

Finally, the paper issues a 'call to arms' for academics and journalists to recognize that, in an age where television rules and 'citizenship' is only one of many dimensions in which people formulate 'political' ideas, discussion and coverage in the mainstream public sphere needs to be at many levels of engagement. The task of providing accessible, entertaining yet authoritative 'ground-level' introductions to political and social issues is essential if the mass of citizens are to remain connected in any meaningful way to the public sphere.

\section{The Public Sphere}

It is not intended here to deal with the intricacies of discussions on the public sphere, nor to recount Habermas's original exposition of the notion from the birth of the public sphere to his belief in its effective murder by the same forces that created it. For a lucid and accessible introduction to Habermas and later developments, see Dahlgren (1995). As a starting point we can consider the public sphere as:

that realm of social life where the exchange of information and views on questions of common concern can take place so that public opinion can be formed (Dahlgren, 1995, 7).

This space or realm, however constituted, idealized or theorized, is essential for democracy; a space where people in their role as citizens can access discussion 
on issues of common concern. However, for Habermas, the public sphere has become a mechanism by which powerful and dominant groups in society capitalist organisations and governments - manufacture consensus through the mass media. The public sphere of today is so dominated by the mass media, that it now makes more sense to talk of a 'mediated public sphere' (Dahlgren, 1995).

In that mediated public sphere, it is argued that the citizen is replaced by the consumer; news has moved from its primary role of constituting public opinion among active citizens to being predominantly driven by commercial considerations (Street, 2001, 42). Arguably, redefining citizens as consumers reduces the associated obligations attached to notions of citizenship, implicitly indicating that there is no civic duty to take part in public life (Savigny, 2005). Critics see declining levels of participation in 'traditional' methods of politics as a sign of a crisis in the public sphere, largely caused by a crisis of legitimacy for news in its role in 'the social construction of public life' (Jones, 2005, 28). The perceived dumbing down of political coverage is seen by many as a primary factor in that crisis of legitimacy.

\section{The 'Dumbing Down' Debate}

As Brian McNair (2003) has recognized, the term 'dumbing down' is offensive, but since this is the term proponents of the thesis have used, this article will follow suit. Dumbing down is usually applied as a derogatory term that refers to the simplifying of a subject towards the lowest common denominator; for example, news is simplified in order to make it more understandable to a larger number of people. Those who argue the necessity for an aware public might ask, 'what's the problem with that'? Supporters of the dumbing down thesis, which has arguably become the 'dominant critical orthodoxy', maintain that:

entertainment has superseded the provision of information; human interest has supplanted the public interest; measured judgement has succumbed to sensationalism; the trivial has triumphed over the weighty; the intimate relationships of celebrities, from soap operas, the world of sport or the royal family are judged more 'newsworthy' than the reporting of significant issues and events of international consequence. Traditional news values have been undermined by new values; 'infotainment' is rampant (Franklin, 1997, 4).

It is not only news - documentary, mainstream TV, magazines, have all dumbed down. For critics, the impact on democratic debate has been considerable, ensuring that structures of power, authority and wealth have been made less visible by the huge growth in lifestyle journalism (Manning, 2001). This is because news and information have become 'commodified' market criteria dominate. The proliferation of media outlets has meant (despite 
conglomeration) an increasingly competitive market as outlets struggle to capture an increasingly fickle audience. Journalists and correspondents complain of pressure to emphasize the sensational, even in mainstream political reporting, hence the huge rise in political reporting that emphasizes 'scandal, corruption and sleaze' (Manning, 2001, 65).

The implication behind such criticisms is that there was a golden age when the media fearlessly stripped back the façade to reveal the underlying structures of dominance in society. While acknowledging that (for example) the radical Victorian press and the alternative regional press of the 1970s did perform this function for their largely working class audiences, such a perception does not reflect the overall history of either print or broadcast media. Historically, the structures of power and authority have never been more than 'partially visible', if that, but their visibility is now arguably higher than it has ever been in the mainstream media. Radical groups know how to get their agenda into the mainstream and coverage of G8 summit protests and political-environmental activism (from Greenpeace to Michael Moore's Bowling For Columbine to Morgan Spurlock's film Super Size Me) has ensured more attention is paid by our media to the activities and underlying patterns of dominance of capitalist organizations and governments than at any previous time. Importantly, it is dumbing down by environmental bodies, journalists and film-makers - that is, delivering an entertaining and newsworthy approach to the topic - which has ensured greater airtime for critical approaches to the dominant capitalist hegemony.

Be that as it may, the attacks on dumbing down continue. Generally, television is seen as the driving force and recent years have seen no shortage of commentators positing a causal link between television's prime position as an entertainment and information medium and a decline in traditional measures of democratic vitality (Putnam, 2000; Manning, 2001; see Jones, 2005, 15-16). The evidence that television news has lowered its standards is ambiguous. While it is undeniable that ITV's evening news programmes pursue a more populist and tabloid agenda than previously - in that its coverage of 'celebrities' and lifestyle topics has increased - its coverage of political issues remains informed and (importantly) accessible to an audience who are not primarily readers of 'broadsheet' newspapers. Also, 'high quality' news coverage is still available on other terrestrial channels (Barnett and Gaber, 2000). The key point is that ITV's and Channel Five's news programmes are designed to engage an audience that does not want the in-depth coverage provided by Channel 4's nightly news or BBC 2's Newsnight.

\section{Newspapers and Dumbing Down}

Redtop newspapers have always been 'sensationalists', even when they embodied high journalistic values, as the Daily Mirror of the 1960s certainly 
did. The need to engage a newly literate audience ensured the first generation of the modern popular press - the Daily Mail launched in 1896, Daily Express in 1900, and Daily Mirror in 1903 — set a template of plenty of pictures, accessible writing and news emphasising human interest factors which is still followed today. It is important to note that 'sensationalism' is not a euphemism for shoddy journalism. Silvester Boham, editor of the Mirror from 1948 to 1953, argued that sensationalism did not mean distorting the truth but rather:

the vivid and dramatic presentation of events so as to give them a forceful impact on the mind of the reader. It means big headlines, vigorous writing, simplification ... Every great problem facing us ... will only be understood by the ordinary man busy with his daily tasks if he is hit hard and often with the facts. Sensational treatment is the answer, whatever the sober and 'superior' readers of other journals may prefer (in Marr, 2005, 96).

Boham's argument still resonates. The mass popular papers, with a more 'userfriendly' approach to the coverage of public affairs, have helped to create an informed and engaged citizenry and arguably still do, despite the widespread belief that Murdoch's Sun has dragged all its peers down-market. The alleged dumbing down of the redtop press, or even of ITV, seems to cause less concern among critics than the belief that dumbing down has spread to quality titles.

Stephen Glover argues that since The Times became available both in tabloid and broadsheet format, Rupert Murdoch has given up maintaining it as an upmarket title (www.theage.co.uk, 16 October 2004). New York Times columnist Anthony Lewis agrees that The Times has dumbed down under Murdoch's ownership, moving from its position as one of the world's great newspapers into a 'shrill, hatchet-wielding, scandal-sheet' (Guttenplan, 1997). Whatever one thinks of Murdoch, it is difficult to equate such allegations with any reasonably dispassionate reading of The Times.

However, for Ian Jack, former editor of The Independent on Sunday, Britain's press have all attempted to become more popular but that, in the process, credibility and trust have been diminished (in Manning, 2001, 65). Former Daily Telegraph editor Peregrine Worsthorne agrees that while both tabloids and broadsheets are better written than ever before, reliability and accuracy have suffered (in Glover, 1999, 173). In short, many critics share the belief that 'quality journalism is in crisis [and that] ... the media's obsession with personalities, opinion, light features and lifestyle pieces is killing the art of reporting' (Cohen, 1998, 18).

\section{Has News Really Dumbed Down?}

Despite the authority behind such arguments, have British newspapers and television news really 'dumbed down'? A more optimistic view is that the 
British media have actually 'brained up' (McNair, 2003). Arguably, there has been a 'democratization of news formats which, in the past, betrayed a cultural elitism' (Manning, 2001, 66). 'If dumbing down means less emphasis on and effort devoted to foreign news, you'd have to say yes,' says Ian Hargreaves, former editor of The Independent. However, Hargreaves warns against the risk of characterizing anything as dumbing down other than high politics and foreign affairs:

Putting more resources into writing about bio-ethics, the breakdown of the family, birth technology - all the issues resulting from the increasing public prominence of women - is a shift in the public agenda that is not really trivial' (in Guttenplan, 1997).

Alan Rusbridger, editor of The Guardian, argues that tabloid techniques stressing opinionated and eye-catching pages are not appropriate for the quality press (Lyall, 2004). The Independent's many superb front pages since going 'compact' demonstrate that such snobbery should be consigned to the dustbin, as former Guardian editor Peter Preston acknowledges:

The truth ... is that tabloid actually suits the current broadsheet news and feature agenda best. It's the natural way of seeking to address segments of a readership which itself is increasingly composed of segments. It forces editors to put their judgment on the line. It establishes its own priorities, not an order of news nicked straight off the $6 O^{\prime}$ clock News on $\mathrm{BBC}$. Tabloid is much more than easy reading on the Tube. It is a means to a disciplined end, a clarity of mind. What took us so long, then? Why was it the autumn of 2003 before The Independent broke the British mould? The obvious answer is fear of looking dumb. Say 'red top' with a curl of the lip (Preston, 2004).

So, although there is agreement that something has changed in political coverage, critics disagree as to the nature of that change. Arguably, news has become more democratic, reflecting the concerns of a wider population rather than the views of a cultural elite; as Cottle observes, 'knowledge is no longer a gift carefully wrapped by experts' $(2001,76)$. Also, an 'elite' of broadsheet readers is now being informed about aspects of popular culture it may otherwise have been ignorant of. Given the connection between political and popular culture - as Street (1997) notes, politics is a form of popular culture and popular culture is a form of politics - such knowledge is crucial for an understanding of contemporary social and political forces. The attitudes of Big Brother contestants may tell us more about cultural mores and attitudes to social issues than any MORI poll. 


\section{In Defence of Dumbing Down - the Need for an Informed Public}

Many critiques are based on an often tacit assumption that if people are 'attracted by personalities and avoid the hard stuff of politics, it is bad for them' (Brants, 1998). As Jones (2005) observes, much criticism of so-called dumbing down comes from a desire to realize a normative ideal of the citizen as a 'rational-critical actor' in public life, an ideal that fails to reflect the variety of ways (from high-minded rationality to the highly emotional) in which people engage with politics. As John Street notes, rational actors base their decisions on factors 'other than policy coherence, political skilfulness or ideological consistency' and the 'performative, aesthetic dimension of the representative relationship cannot be eliminated' (2004, 444).

Criticisms of dumbing down can also be viewed as a response to the feminization of journalism, a movement away from a male-dominated news agenda (see Livingstone and Lunt, 1994). The rise in consumer and life-style coverage:

might just as readily be interpreted as the positive influence on journalistic agendas of the rise of feminism, bringing with it a new visibility for what were once dismissed as 'women's issues' ... [it can be argued] that 'the professional advances of women in recent years have feminised and humanised what was hitherto a male-dominated news agenda ... less pompous, less pedagogic, less male, more human, more vivacious, more demotic (McNair, 2003, 50-51).

While acknowledging the potential offence to women - who might feel the suggestion seems to be that they are less interested in politics than in 'shopping' - the thrust of the argument is that news coverage has moved away from an obsession with rational discourse to embrace the emotional, and that this reflects, in particular, the desire of a female audience. The coverage of the death and funeral of Diana, Princess of Wales, vividly illustrates the polity's willingness to display its emotions publicly. Although many commentators have criticized such excessive displays (West, 2004), emotional attachment is not necessarily a negative factor in our relationship with public figures.

Ornebring and Jonsson persuasively argue that an appeal to the emotions can stimulate political participation, indicating that sensationalism and simplification are 'not necessarily opposed to serving the public good' (2004, 284, emphasis in original: see also van Zoonen, 2004, 48). Lunt and Stenner support the argument that deliberation in complex pluralistic societies involves 'strongly held emotions that need to be faced, expressed and reflected upon' $(2005,76)$. If this means presenting politics in a more accessible and exciting way, such as more direct public questioning of politicians or in the introduction of 'Vote For Me' type programmes (see below), then those with an interest in increasing political participation should embrace this. 
News coverage that fails to make politics exciting and relevant is counterproductive. To illustrate, some critics have drawn a relationship between a dumbing down of the local press and a failure to engage local voters (Franklin, 2003). However, it could be strongly argued that local newspapers' responsibility may lie not in their alleged dumbing down or in any failure to cover local politics in sufficient detail, but in their continuing commitment to high journalistic standards, a balanced approach to candidates and a commitment to 'rational' debate (Temple, 2005). Given the wide educational spread of their readership, a failure to adopt at least some 'tabloid' coverage of local politics will fail to engage a large number of their readers.

\section{Engaging an Audience - 'Interactive' Politics}

Politics cannot set itself up above other areas of interest. It is useless for political elites to bemoan the rise of infotainment. The 'public' only exists when it is active, and it needs to be captured or engaged (Warner, 2002, 87). The argument that tabloid journalism 'has little or nothing to contribute to the life of the citizen' (Sparks, 2000, 29) ignores the importance of engaging the ignorant and disenfranchized. Those of the population generally uninterested in formal politics - the majority - need, at the very least, to be informed about basic issues, but they will not engage with 'top-down' coverage which assumes all readers or viewers are aware of the minutiae of political debate. Engaging and entertaining political coverage could encourage further examination of the issues at a more informed level; once people are engaged with an issue they are more likely to seek further and perhaps more advanced information.

Stanyer's argument that 'audience interaction is now almost a prerequisite for political output' $(2004,14)$ is demonstrated by audience participation on Question Time, Sky News's audiences with the political leaders (which involved some tough questioning from the studio audience) and the all-pervasive interactive button that facilitates audience response to questions of the day in an increasing number of news and current affairs programmes. It is certainly the case that, as Stanyer $(2004,23)$ notes, people are now more willing to participate via non-traditional means such as interactive television polls, emailing, wearing armbands and boycotting goods and services.

Whatever their drawbacks, the growth of blogging and Usenet groups demonstrate the possibility of creating new spaces for deliberation within the public sphere. However, research indicates that participation is dominated by the better-educated middle classes (Stanyer, 2004, 21-23) and Ofcom has found that electronic politics benefits the politically aware and fails to reach the 'politically marginalized' (Hudson, 2005). That said, on-line 'civic networks' raise concerns mainstream media can miss, whether mobilizing to protest 
against the World Trade Organisation (see Cottle, 2001) or the BBC's broadcast of Jerry Springer The Opera, and evidence suggests that online political activity 'might be the largest area of impact on a citizen's sense of efficacy' (Hudson, 2005). That ideas challenging the dominant hegemony can emerge from alternative spheres and become 'mainstream' is not in doubt environmental issues are one example.

Also, that the views of many people are not expressed in any 'mainstream public sphere' is arguably demonstrated by the public's selection of convicted fraudster Rodney Hylton-Potts as a parliamentary candidate in the ITV show Vote For $M e$, although his extreme right-wing views seemed to support concerns that the programme was a blow to democracy. On the contrary, for former Sun editor Kelvin MacKenzie (2005), Hylton-Potts's win demonstrates the degree of public opposition to the liberal consensus (although allowing viewers to cast multiple telephone votes might tend to distort the alleged representational element of the exercise). For MacKenzie, that subjects such as castration for paedophiles, the legalizing of all drugs and banning all immigration (part of the winner's platform) remain off limits in the mainstream public sphere (not the terminology used by MacKenzie), demonstrates the closed nature of most political coverage. ITV were also bullish about the programme, arguing that it had 'raised the level of debate about politics' at the same time as engaging people in the process (The Observer, 16 January 2005).

Despite this, the suspicion remains that ITV were embarrassed by the programme and the selection of Hylton-Potts. ITV buried it in the late night schedules, ensuring that the programme failed to grab the sort of tabloid audience who might have been attracted to its Pop Idol format. Given there are no plans to repeat the ostensibly ground-breaking programme, it is easy to dismiss the motives and utility of Vote For Me. It is certainly the case that most broadsheet commentators saw it as an essentially risible exercise.

Much of the concern about new methods of engagement appears to be elitegenerated distaste at methods that generally bypass traditional methods of issue formation such as political parties (Garnham, 1986). The young, in particular, are less willing 'to invest significant time in expressing themselves through collective means' and are more likely to engage in more 'individualistic activities' such as blogging (Stanyer, 2004, 21). The Net is seen by some as embodying the Habermasian ideal of a space where freedom of speech and information is a reality; those who see new information technology as a chance to strengthen democracy by including more people in public discourse seem to believe that if people had easy access to the public sphere they would participate more (see Stolterman, 2002, 1, who offers a critique of such reasoning). An alternative reality is that the Net provides (at the moment) merely an 'illusion of a public sphere', as the sheer scale of information makes participation in debate (rational-critical or otherwise) unlikely, except by access 
to already well-established news sites such as BBC Online. At present, even on the Net, 'elites remain the gatekeepers of the boundaries of public information and opinion formation' (Savigny, 2002, 7), as most people need an informed and authoritative précis of often complex events.

\section{The Need for a Broader Conception of the Public Sphere}

Public sphere theory seems 'oddly removed from the empirical realities it claims lie at its centre, namely the processes of public opinion' (Dahlgren, 2004, 17); the way public opinion is 'formed' extends far beyond any traditional notion of a rational-critical, political public sphere. Also, as Yeatman points out 'democratic discourse that is oriented in terms of a centric public sphere is truly anachronistic' $(1994,113)$. Critics fail to appreciate that there needs to be a 'reconceptualization of the public sphere' to more accurately reflect that what Dahlgren (1995) has called the 'mediated public sphere' comprises many (and multi-dimensional) public spheres. As McNair observes:

The public sphere, once a restricted space of journalism and commentary available only to white, male, educated elites, has expanded ... to the point of genuine mass accessibility ... [those] who dismiss 'popular tastes' ... assume that the minutiae of policy and the in-fighting of political elites are the only subjects of legitimate journalistic interest ... they exclude the possibility, too, that subjects of human interest are not at the same time important in the economic and policy spheres (McNair, 2003, 48-49).

It is important that alternative media exist which can help 'privilege the powerless and the marginal' and offer competition to, and a route into, the mainstream public sphere. However, 'alternative politics' - the politics of talk and reality shows, soap operas, Hello magazine, The Jerry Springer Show also offer 'citizens' a doorway into the discussions of the 'mainstream public sphere'; in the face of much prejudice against the alleged superficiality of 'women's talk', Oprah Winfrey maintains her show is programmed to empower women (Livingstone and Lunt, 1994, 42-43). Story lines tackling abortion in Coronation Street, drug taking in Grange Hill, anti-social behaviour on Trisha, or politicians being gently quizzed on Richard \& Judy all offer a potential route into political debate and action.

It might be asked whether the notion of a public sphere, however constituted, is still viable (see Allan, 2004). However, we need to live together, communicate, and 'trust that we're part of a shared world' (White, 2005, 3). So some notion of a shared reality - for political engagement, a shared mainstream public sphere - is essential. However, the media landscape could be conceptualized 'as consisting of a mainstream and a number of alternative spheres - spheres from which marginalized groups strive to gain access to and 
representation in, the mainstream' (Ornebring and Jonsson, 2004, 285). There has been a shift in the public sphere literature away from using Habermasian rational conceptions and towards 'a focus on issues of voice, the expression of marginal experiences and identities' (Lunt and Stenner, 2005, 76).

The mainstream public sphere cannot be composed purely of 'rationalcritical' elements; it must reflect the public's engagement with politics, which is often anything but rational. When listeners to the Today programme, which could be seen as a key component of the rational-critical public sphere, were asked to back a parliamentary bill, they chose one that would enable home owners to tackle intruders without fear of prosecution - in the wake of the Tony Martin case, largely an emotionally informed issue. ${ }^{1}$

As McNair (2003) points out, society is composed of many publics so why not many public spheres? Research has found that people of all ages and backgrounds use many genres (especially entertainment media) to make sense of the political world. The narrative's plausibility (whether news or fiction) is central - does it ring true with their experience? When the narrative is seen as plausible, then the discourses of television are incorporated into a viewer's own political understanding (Jones, 2005, 23). This does not suggest a disengaged or passive audience, nor an audience incapable of or uninterested in discussing serious political issues that are raised in 'non-political' programming; in any case, the distinction between popular and political culture 'is almost entirely artificial' (Street, 1997, ix). We are all members of many spheres of activity, all of which are capable of influencing our beliefs and actions, so such public spheres will be multi-dimensional and overlapping (see McNair, 2003, 51-52).

\section{Rethinking our Engagement with Politics}

What Jones has called 'new political television' seems to exemplify key elements of any reconceptualization of the public sphere. 'New political television' is characterized by:

the lack of commitment to traditional political bodies and the rejection of elite formulations about politics, including the exclusionary language used by experts and political insiders; the mix-and-match approach to political values and ideas by new television commentators and public alike; the populist impulse to project and hear the voices of ordinary people (including oneself) and the usage of new media and communication technologies to achieve this; the small and fragmented yet committed audiences attentive to new offerings in political communication; and the porous nature of politics within and across popular cultural formats (Jones, 2005, 21).

For Jones, such an approach is more grounded in popular culture and is an important development for citizen engagement; crucially, we need to 'rethink 
what engagement with politics means' (2005, 30). Dumbing down cuts both ways - shows such as Jerry Springer offer 'an opportunity for communication across social divisions' which is a key assumption of the public sphere concept (Lunt and Stenner, 2005, 69). While there is evidence (Prior, 2005, 287) to indicate that greater media choice has created a tendency for people with a preference for entertainment to 'tune out of politics completely' (and if so, entertainment shows that feature issues become even more crucial in connecting those viewers with the mainstream public sphere) it is clear that citizens of all backgrounds do not 'segregate their practices of citizenship into 'information' over here, 'entertainment' over there' (Jones, 2005, 31).

Dahlgren (1995) has argued that politics barely exists as a reality outside the media and if so then politicians must create an audience; 'political performance has to be understood in similar terms to those applied to popular culture' (in Jones, 2005, 17). Postman's (1987, 4) anguish at the transformation of American politics and news into 'congenial adjuncts of show business' - and the 'culpability' for that must rest with all partners in the relationship, including citizens - underlines the necessity for adaptability by politicians. If politicians seek alternative ways of reaching the public it may also be partly to counter the generally negative coverage of their activities by the mainstream news media who, in the interests of 'show business', have emphasized the prurient and sensational. Talk shows, for example, in which politicians increasingly appear, tend to emphasize personal qualities in a non-confrontational manner which does not stress 'tough issue-oriented questions or partisan debate' (Baum, 2005, 215; see also Drake and Higgins, 2006). Baum's research also strongly suggests that 'many Americans who might otherwise have ignored the presidential campaign entirely, were ... exposed to at least some information about the candidates prior to the election' and that 'politically unaware' Americans are far more prone to be persuaded than the more politically aware (ibid., 230). Millions of American voters (and British voters are unlikely to differ significantly) made their decisions about candidates based on personal characteristics rather than on public policy issues (ibid, 231).

\section{The Importance of Public Service Ideas}

For McNair (and also for Garnham, 1986) there is one key element of the public sphere and that is the continued health and integrity of public service broadcasting:

just as 'the public' to be served has gradually come to be viewed as a network of overlapping and interacting 'publics' rather than a homogenous whole, public service journalism must adapt to reflect the new cultural context ... in a competitive resource-squeezed system, the public service apparatus 
becomes even more important as an example of best practice, setting a standard which Sky News and other new entrants to the journalism market are obliged to match or at least approximate to (McNair, 2003, 52).

So - the BBC is an important part of our mainstream public sphere and help minimize a general lowering of 'standards', but that does not mean other media are significantly less important. As McNair (ibid.) points out, some media 'are dumber than others. But so are some people [and] ... there is room enough in the public sphere for every taste and preference'.

The public sphere cannot be 'separated' from other spheres of human activity and especially not in our role as consumers. We are both citizens and consumers and those boundaries are becoming blurred. Increasingly, as consumers we are making decisions based on ethical and moral issues which must be described as 'political'. The essentially unorganized public boycott of South African products and the increasing popularity of fair trade goods, organic produce and ethical share portfolios, offer evidence of this intermingling of our political beliefs and lifestyle choices. We have multiple (and overlapping) identities, of which citizen is just one (Dahlgren, 1995); we construct our own ' $a$ la carte politics through adhocing, mixing and individualizing social and political positions' (Jones, 2005, 20).

\section{Farewell to Elite Conceptions of the Public Sphere}

Therefore, it makes sense to see 'the mainstream public sphere' as one of a series of overlapping spheres. McNair (2000, Figure 2.1, 30) offers such a model but his political public sphere is limited to traditional news media. Any model must include all spheres of human activity. At the risk of proposing a model that includes everything and therefore explains nothing, a conception of the public sphere that does not allow for access from all areas will fail to 'represent the multitude of ways in which people exchange, process and engage political material in their day-to-day lives' (Jones, 2005, 18).

A criticism that could be made of the approach suggested here is a lack of 'discrimination' in that all types of discourse, no matter how reprehensible to liberal sensitivities, must be admitted to the public sphere. Indeed, McGuigan (1992, 76-79) has argued the importance of academics making such 'qualitative judgements' and believes a refusal to use such powers of discrimination is essentially an abrogation of responsibility. McGuigan's backlash against postmodernism's values (or lack of values) inevitably produced its own backlash, with Storey mocking the desire by university lecturers to be the 'guardian of the eternal flame of the cultural' (Storey, 1993, 200-201; see also Street, 1997, 147-167). It is quite extraordinary to see the passion and overt hostility aroused among academics by the suggestion that, for example, the 
News of the World's naming and shaming of paedophiles might (whatever one thinks of their approach) contribute to public debate and therefore enhance the public sphere. Critics, that is, some elite academics in this instance, allow that popularizing or sensational approaches of the Michael Moore ilk or the campaigning Daily Mirror of the 1960s make a contribution, but bridle at the inclusion of Jerry Springer, 'naming and shaming' campaigns, or BNP campaign literature in their conception of the public sphere (PSA Media and Politics group sessions, University of East Anglia, November, 2005). However, at the very least the News of the World's campaign has forced opponents of such tactics to articulate and defend their position, perhaps (who knows) contributing to some supporters of 'naming and shaming' reconsidering their own position.

Central to the conception of a reconceptualized public sphere is the abandonment of elite perceptions of what is or is not permissible in 'civilized' debate. Working class opinion on, for example, immigration, capital punishment or race is often assumed to be the result of false consciousness from media (especially tabloid) manipulation (Watson, 2003, 107-108). Such assertions reinforce the pejorative way in which dumbing down is referred to in the literature and the way in which 'popular taste and discourse' is patronized by an elite which appears to believe in the innate superiority of its own value judgements. This is by no means confined to the academic community, as was shown when Arundati Ray won the Booker Prize in 1997, sparking press claims that she represented a dumbing down of the prize as her novel was too populist and she was too pretty (see Street, 2005, 833).

The argument for the importance of considering popular culture as an essential element in debates about political issues, no matter how trashy, racist or debased such culture may seem to those of 'heightened' sensibility, is not only about engaging the public but also about challenging such elite perceptions of what is legitimate discourse in the public sphere.

\section{A Call to Arms for Social Scientists: Informed Tabloid Journalism}

Allan asks how journalism can 'best fulfill its social responsibilities' to the public sphere:

In what ways will journalism have to change in order to enhance civic participation in government, and thereby help to close what is clearly a widening gap between those with 'information capital' and those without it? (Allan, 2004, 216).

Of course, for many, the idea that this should be a function of market-place journalism is debatable — such 'social responsibilities' could arguably be left to 
the $\mathrm{BBC}$, who as McNair notes (above) compel other news broadcasters to at least pay lip service to 'quality' news programmes.

There is more authoritative and in-depth political writing available than ever before (see also McNair, 2000, 40) but it is undeniable that much of what passes for political information today is superficial. At least equally important, the world-view given in the coverage of politics by some newspapers and broadcast news programmes is often partial, relatively uninformed and/or inaccurate. What is needed are quality 'dumbed down' pieces, aimed at the tabloid market, talking about politics from an informed, analytical perspective, but in a manner and style that might (just) draw the uninterested tabloid reader in. Richard Littlejohn is a brilliant and often witty tabloid columnist (interestingly, an observation guaranteed to enrage some academics at conferences) but he too often feeds the prejudices of his audience rather than seeking to challenge them. When he does challenge, with his often-unorthodox views on social issues such as policing, he must cause his readers to question the common-sense explanations the dominant hegemony of liberal-democratic capitalism has instilled concerning, for example, the role, competence and powers of the police in modern society.

Political scientists rarely 'engage' outside of an elite 'broadsheet' audience. This may be because they are incapable of writing effective tabloids, a muchmocked and unappreciated journalistic skill. We leave tabloid 'political' commentary to those such as Littlejohn, who are seldom restrained by notions of balance or even accuracy. It may also be because tabloid editors (television and newspaper) do not perceive their audience as wanting 'political' debate and will therefore be highly unlikely to give space to serious discussion, however entertainingly provided. However, they are not the only media outlets into the mainstream public sphere. The place where such issues can certainly be raised is the local and regional press, despite beliefs about their slide into 'McJournalism' (Franklin, 2005). Their importance in setting the political agenda is becoming increasingly clear, especially at election times (see Temple, 2005). The opinion columns of local newspapers, with their wide-ranging audience and their reputation as trustworthy carriers of information, offer a potentially fruitful route for academics to address the public on serious issues in a dumbed down but not dumb fashion. Local radio, especially the BBC's network of local and regional stations, offers the same potential.

The public has choice now - that choice may be largely illusory, but it does mean that they are capable of constructing their own individualized public sphere. Politics, like any largely mediated activity, must seek an audience but it may also need to create an audience. That audience will be one whose engagement with politics has been primarily mediated through popular entertainment such as talk shows or reality programmes. Such an audience 
has to be engaged and it will not be engaged by being bored. Whether we like it or not, 'dumbing down' is here to stay.

\section{Note}

1 Of course, the same criticisms made about Vote for Me's telephone voting methods could also be made about Today's exercise. Listeners could make as many votes as they were prepared to pay for, distorting and weakening claims for the outcome that it accurately represented 'public opinion'.

\section{References}

Allan, S. (2004) News Culture, Maidenhead: Open University Press.

Barnett, S. and Gaber, I. (2000) From Callaghan to Kosovo: Changing trends in British television news, 1975-1999, London: ITC.

Baum, M.A. (2005) 'Talking the vote: why presidential candidates hit the talk show circuit', American Journal of Political Science 49(2), 213-234.

Brants, K. (1998) 'Who's afraid of infotainment?', European Journal of Communication 13(3), 315-335.

Cohen, N. (1998) 'The death of news', New Statesman, 22 May.

Cottle, S. (2001) 'Television news and citizenship: packaging the public sphere', in M. Bromley, (ed.) No News is Bad News: Radio, Television and the Public, Harlow: Longman.

Dahlgren, P. (1995) Television and the Public Sphere: Citizenship, Democracy and the Media, London: Sage.

Dahlgren, P. (2004) 'Theories, boundaries and political communication: the uses of disparity', European Journal of Communication 19(1), 7-18.

Drake, P. and Higgins, M. (2006) 'I'm a celebrity, get me into politics: the political celebrity and the celebrity politician', in S. Holmes and S. Redmond (eds.) Understanding Celebrity Culture, London: Routledge.

Franklin, B. (1997) Newszak and News Media, London: Arnold.

Franklin, B. (2003) 'Talking past each other: journalists, readers and local newspaper reporting of general election campaigns in the UK', Paper presented at the Political Studies Association's Media and Politics Group symposium Can't Vote, Won't Vote, Goldsmiths College, 6 November.

Franklin, B. (2005) 'McJournalism: the local press and the McDonaldization thesis', in S. Allan (ed.) Journalism: Critical Issues, Maidenhead: Open University Press.

Garnham, N. (1986) 'The media and the public sphere', in P. Golding, G. Murdock and P. Schlesinger (eds.) Communicating Politics, Leicester: Leicester University Press.

Glover, S. (ed.) (1999) Secrets of the Press: Journalists on Journalism, London: Allen Lane.

Guttenplan, D.D. (1997) 'Britain: dumb and dumber? A transatlantic spat over the quality of the "quality press", Columbia Journalism Review, July/August 1997, 36(2).

Habermas, J. (1989) The Structural Transformation of the Public Sphere, Cambridge: Polity Press.

Hudson, R. (2005) 'E-politics wins a vote of confidence', The Sunday Times, 13 March.

Jones, J. (2005) Entertaining Politics, Oxford: Rowman \& Littlefield.

Livingstone, S. and Lunt, P. (1994) Talk on Television: Audience Participation and Public Debate, London: Routledge.

Lunt, P. and Stenner, P. (2005) 'The Jerry Springer Show as an emotional public sphere', Media, Culture \& Society 27(1), 59-81. 
Lyall, S. (2004) 'UK 'tabloids' reshape press landscape', International Herald Tribune, 29 March.

MacKenzie, K. (2005) 'What this is telling the cabinet: listen to the 'nasty' people, too", The Sunday Times, 23 January.

Manning, P. (2001) News and News Sources: A Critical Introduction, London: Sage.

Marr, A. (2005) My Trade: A Short History of British Journalism, London: Pan.

McGuigan, J. (1992) Cultural Populism, London: Routledge.

McNair, B. (2000) Journalism and Democracy: An Evaluation of the Political Public Sphere, London: Routledge.

McNair, B. (2003) News and Journalism in the UK, London: Routledge.

Ornebring, H. and Jonsson, A.M. (2004) 'Tabloid journalism and the public sphere: a historical perspective of tabloid journalism', Journalism Studies 5(3), 283-295.

Postman, N. (1987) Amusing Ourselves to Death, London: Methuen.

Preston, P. (2004) 'Tabloids: only the beginning', British Journalism Review 15(1), 50-55.

Prior, M. (2005) 'News $v s$ entertainment: how increasing media choice widens gaps in political knowledge and turnout', American Journal of Political Science 49(3), 213-234.

Putnam, R. (2000) Bowling Alone: The Collapse and Revival of American Community, New York: Simon \& Schuster.

Savigny, H. (2002) 'Public opinion, political communication and the internet', Politics 22(1), 1-8.

Savigny, H. (2005) 'Political marketing: what's democracy got to do with it?, Paper delivered to PSA Annual Conference, University of Leeds, 6 April.

Sparks, C. (2000) 'The panic over tabloid news', in C. Sparks and J. Tulloch (eds.) Tabloid Tales: Global Debates Over Media Standards, Lanham: Rowman \& Littlefield.

Stanyer, J. (2004) 'The British public and political attitude expression: reconceptualising the role of the public in the field of political communication', Paper presented at Spin, Image and the Media Conference, Maison Francaise, Oxford, 19-20 November.

Stolterman, E. (2002) 'Unintended use: The 'public sphere' designed by the public' www.informatik.umu.se 28 March.

Storey, J. (1993) An Introductory Guide to Cultural Theory and Popular Culture, Hemel Hempstead: Harvester Wheatsheaf.

Street, J. (1997) Politics and Popular Culture, Cambridge: Polity.

Street, J. (2001) Mass Media, Politics and Democracy, Basingstoke: Palgrave.

Street, J. (2004) 'Celebrity politicians: popular culture and political representation', British Journal of Politics and International Relations 6, 435-452.

Street, J. (2005) 'Showbusiness of a serious kind: a cultural politics of the arts prize', Media, Culture \& Society 27(6), 819-840.

Temple, M. (2005) 'Carry on campaigning: the case for 'dumbing down' in the fight against local electoral apathy', Local Government Studies 31(4), 415-431.

van Zoonen, L. (2004) 'Imagining the fan democracy', European Journal of Communication 19(1), $39-52$.

Warner, M. (2002) Publics and Counterpublics, New York: Zone Books.

Watson, J. (2003) Media Communication: An Introduction to Theory and Process, Basingstoke: Palgrave Macmillan.

West, P. (2004) Conspicuous Compassion, London: Civitas.

White, C. (2005) The Middle Mind: Why Consumer Culture is Turning us into the Living Dead, London: Penguin.

Yeatman, A. (1994) Postmodern Revisionings of the Political, New York: Routledge. 